\title{
A glimpse on biological activities of tellurium compounds
}

\author{
RODRIGO L.O.R. CUNHA, ${ }^{1,2}$ IURI E. GOUVEA ${ }^{2}$ and LUIZ JULIANO ${ }^{2}$ \\ ${ }^{1}$ Departamento de Ciências Exatas e da Terra, UNIFESP, Rua Artur Riedel, 275, Jardim Eldorado, 09972-270 Diadema, SP, Brasil \\ ${ }^{2}$ Departamento de Biofísica, UNIFESP, Rua Três de Maio, 100, Vila Clementino, 04044-020 São Paulo, SP, Brasil \\ Manuscript received on June 27, 2008; accepted for publication on September 18, 2008; \\ contributed by LUIZ JULIANO*
}

\begin{abstract}
Tellurium is a rare element which has been regarded as a toxic, non-essential trace element and its biological role is not clearly established to date. Besides of that, the biological effects of elemental tellurium and some of its inorganic and organic derivatives have been studied, leading to a set of interesting and promising applications. As an example, it can be highlighted the uses of alkali-metal tellurites and tellurates in microbiology, the antioxidant effects of organotellurides and diorganoditellurides and the immunomodulatory effects of the non-toxic inorganic tellurane, named AS-101, and the plethora of its uses. Inasmuch, the nascent applications of organic telluranes (organotelluranes) as protease inhibitors and its applications in disease models are the most recent contribution to the scenario of the biological effects and applications of tellurium and its compounds discussed in this manuscript.
\end{abstract}

Key words: antitumorals, biological applications, enzyme inhibitors, organotellurium, proteases, tellurium.

\section{INTRODUCTION}

Tellurium is a rare element which has been regarded as a non-essential, toxic element. Several literature reports also stress that its compounds are highly toxic. Interestingly, selenium was also considered a highly poisonous element since the commencement of selenium related science, until it got the status of being an absolute poison. This pre-concept fell when selenium was identified as a micronutrient for bacteria, mammals and birds (Schwarz and Foltz 1957). Selenium was found in the active site of mammalian gluthathione peroxidase as the unique $21^{\text {st }}$ amino acid, selenocysteine (Chambers et al. 1986, Hatfield and Gladyshev 2002). The number of known selenoenzymes greatly grew as well as the mechanisms by which those enzymes act. By now, tellurium biology and biochemistry face the same prejudice of selenium, before

In commemoration of the $75^{\text {th }}$ anniversary of Escola Paulista de Medicina / Universidade Federal de São Paulo. * Member Academia Brasileira de Ciências Correspondence to: Dr. Rodrigo L.O.R. Cunha E-mail: rlorcunha@unifesp.br / rodrigo.lor.cunha@gmail.com the recognition of its biological role. The chemistry of tellurium has a plethora of reactivity patterns but its biochemistry is far less recognized than selenium. Therefore, there are plenty of opportunities for the development and establishment of tellurium participation in the scenario of Biology and Medicine. Earlier, thorough reviews concerning other aspects of tellurium compounds were published, in relation to both their chemistry (Comasseto et al. 2007) and their pharmacological aspects (Nogueira et al. 2004). This short review we present herein has the aim to introduce a diversified view on the biological effects of tellurium compounds.

\section{GENERALITIES AND DEFINITIONS}

Tellurium comes from the Latin "tellus", meaning "earth", and was discovered by F.J. Mueller von Reichenstein in 1782 from ores mined in the gold districts of Transylvania (Bragnall 1966, Cooper 1971). Müller called it metallum problematicum or aurum paradoxum because it did not show any property of antimony, a known impurity of gold. The discovery of tellurium 
occurred few years after the discovery of oxygen by J. Priestley and C.W. Scheele, though the periodic group relationship between the other chalcogens was not apparent until nearly a century later. Tellurium is occasionally found native, but is more often found as the telluride of gold (calaverite) or combined with other metals. In the environment, $\mathrm{Te}$ exists in its elemental $\left(\mathrm{Te}^{0}\right)$, inorganic -telluride $\left(\left(\mathrm{Te}^{2-}\right)\right.$, tellurite $\left(\mathrm{TeO}_{3}^{2-}\right)$, and tellurate $\left(\mathrm{TeO}_{4}^{2-}\right)$ ), and organic (dimethyl telluride $\left(\mathrm{CH}_{3} \mathrm{TeCH}_{3}\right)$ ) forms (Cooper 1971). Of these, its oxyanion forms are more common than its non-toxic, elemental state (Summers and Jacoby 1977). Presently, sparse research into anthropogenic emissions of tellurium-based compounds has been conducted and the implications of Te in the air have yet to be investigated. Tellurium is a member of the family of chalcogens. The German chemist Wilhelm Blitz coined the term "chalcogen" ("ore formers" from chalcos, old Greek for "ore") for these elements, and "chalcogenides" for their compounds (Fischer 2001). Tellurium and selenium generate compounds that are structurally related to their sulfur analogues, but exhibit different properties and reactivities, being thus considerably more toxic. As one descends the column, the chalcogens become larger and more polarizable than sulfur. Selenium has a lower electronegativity and forms weaker bonds than sulfur (Whitham 1995). The chemists found that selenium can be easily introduced into molecules as a radical, a nucleophile, or an electrophile. Tellurium has even greater metal like properties and is a true metalloid. In part, due to its polarizability, the C-Se bond is weaker than C-S bonds; $\mathrm{C}$-Te bonds are weaker yet, specially in the case of alkyl derivatives which tend to decompose under heat and light irradiation. This difference in bond energies may explain why telluromethionine and tellurocysteine amino acids have not been naturally found while selenocysteine (the $21^{\text {st }}$ amino acid) has been found in many organisms.

\section{Main Classes of Tellurium Compounds}

Tellurium composes both inorganic and organic derivatives. An inorganic tellurium compound differs from an organic derivative because the former has at least one tellurium-carbon bond in its structure. A number of different classes of organotellurium compounds are known. The main classes are depicted in Chart 1. Those classes can be divided in two distinct groups according to the oxidation state of tellurium. The first group contains the divalent derivatives. Tellurols are the analogues of alcohols and thiols and are readily susceptible to oxidation to ditellurides. Diorganotellurides are the analogues of ethers and tioethers, have a formal oxidation state of -2 and comprises the large set of studied organotellurium compounds. Diorganoditellurides are related to peroxides, being the products of oxidation of tellurols. The second major group is composed by the hypervalent derivatives in which tellurium has the oxidation states of +4 and +6 , and the classes of organotelluranes composed by organotellurium trihalides, diorganotellurium dihalides, organotellurium oxides, organotellurates, and organopertelluranes (Chart 1).

\section{Biological EfFects of Elemental Tellurium AND ITS INORGANIC DERIVATIVES}

Tellurium found historical applications in the treatment of microbial infections prior to the discovery of antibiotics. Early documentation in 1926 reports its use in the treatment of syphilis and leprosy (De Meio and Henriques 1947). Its oxyanion tellurite, $\mathrm{TeO}_{3}^{2-}$, has been used in microbiology since the 1930s when Alexander Fleming reported its antibacterial properties (Fleming 1932, Fleming and Young 1940). In 1984, it was suggested that $\mathrm{TeO}_{3}^{2-}$ could be a potential antisickling agent of red blood cells in the treatment of sickle cell anemia (Asakura et al. 1984). In 1988, tellurium-containing immunomodulating drugs were proposed as treatment agents for AIDS; however, little has been done on it since then (Jacobs 1989). This compound, AS-101, inhibits the production of IL-10, IFN- $\gamma$, IL-2R, and IL5 (Shohat et al. 2005), and also exhibits protection of bone marrow stem cells during chemotherapy (Guest and Uetrecht 2001). More recently, it has been found other diverse activities of AS-101, such as the induction of hair growth in both nude mice and in teenagers with alopecia (Sredn et al. 2004); the inhibition of IL-1 $\beta$ converting enzyme (caspase-1) (Brodsky et al. 2007); protection against homocysteine-promoted apoptosis (Okun et al. 2007a); the enhancement of neuronal survival in an ischemic stroke animal model (Okun et al. 2007b); and the protection and restoration of dopaminergic neurons in a Parkinson's disease model (Sredni et al. 2007). 
Tellurium(II) compounds

Hypervalent tellurium compounds

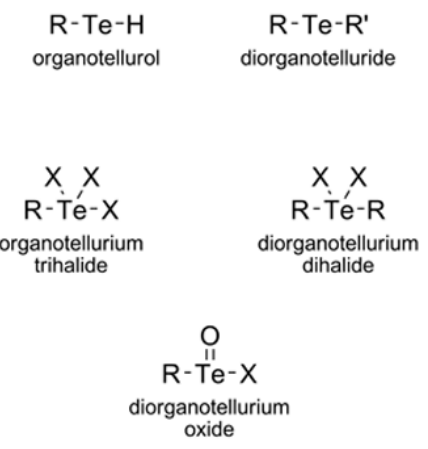

$\mathrm{R}-\mathrm{Te}$ Te-R

diorganoditelluride

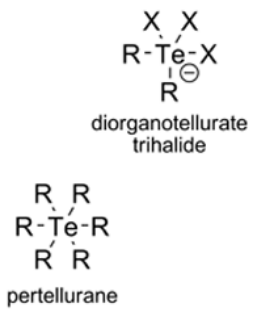

Chart 1 - Classes of tellurium compounds mainly explored for the study of biological effects.

Tellurium biochemistry in the context of animal and human toxicology was last reviewed by Taylor (1996). Despite many chemical homologies between selenium and tellurium, a nutritional role has never been identified for tellurium. Moreover, tellurium, at low concentrations, induces both acute and chronic toxicity in a variety of organisms. Nevertheless, several studies have shown that trace amounts of tellurium are present in body fluids, such as blood and urine (Goulle' et al. 2005). Tellurocysteine and telluromethionine can be found in bacteria (Boles et al. 1995, Budisa et al. 1995, 1997), yeast (Yu et al. 1993), and fungi (Ramadan et al. 1989) as a result of misincorporation of tellurium in place of sulfur or selenium, thus allowing the expression of protein analogs useful for protein structural studies (Moroder 2005).

The toxicology of tellurium has been received less attention than that of selenium. This may be a result of the less frequent contact of man and animals with this element and its compounds. Tellurium is less soluble than selenium in physiological $\mathrm{pH}$ and the oxidation to tellurite $\left(\mathrm{TeO}_{3}^{2-}\right)$, tellurate $\left(\mathrm{TeO}_{4}^{2-}\right)$ or $\mathrm{TeO}_{2}$ occurs easily. Tellurium dioxide is practically insoluble in water at physiological $\mathrm{pH}$. The reduced form of tellurium, $\mathrm{H}_{2} \mathrm{Te}$, more readily decomposes, by light or air, than $\mathrm{H}_{2} \mathrm{Se}$; for this reason, some authors attribute to tellurium a lower potential toxicity than selenium (Sadeh 1987).

Both tellurium and/or its oxyanion forms act on the enzyme squalene monooxygenase, the second enzyme in the committed pathway for cholesterol biosynthesis. From the blockage of cholesterol synthesis, a transient demyelination of peripheral nerves occur (Wagner-Recio et al. 1991, Wagner et al. 1995). The same effect has been observed with selenite and other methylselenium compounds (Gupta and Porter 2002). The sensitivity of squalene monooxygenase to tellurium and selenium compounds is due to the binding of these compounds to vicinal cysteines; the methylation of tellurium in vivo may enhance the toxicity of tellurium for this enzyme (Laden and Porter 2001). It has also been observed that tellurite $\left(\mathrm{TeO}_{3}^{2-}\right)$ ions induce the alteration of the erythrocyte membrane and this activity is thiol-dependent as well (Deuticke et al. 1992). Finally, most of the Te(IV) derivatives are also able to inactivate cysteine proteases, but not other families of proteases. This seems to be related to the ability of Te(IV) compounds to react with the thiolcatalytic site of cysteine proteases. $\mathrm{Te}(\mathrm{VI})$ compounds do not exhibit any such inhibitory activity as they are inert towards thiol moieties (Albeck et al. 1998). Overall, the above work suggests that tellurium compounds interact with biological systems by specific chemical interaction with endogenous thiols. More recently, another inorganic tellurium compound, named SAS, was synthesized, and the inhibitory activity toward papain and cathepsin B described as more potent than AS-101 as cysteine protease inhibitor (Yosef et al. 2007).

The precise biochemical explanation for the toxicity of oxyanions of the different chalcogens remains largely unknown in bacteria. In general, it has been assumed that the toxicity of tellurite is a consequence of the strong oxidizing properties that lead to the formation of deleterious reactive oxygen species (Tremaroli et al. 2007).

Tellurium and its inorganic compounds are biologically reactive and interact with organisms in a specific 
way. Some living organisms display can process nonessential tellurium. As a form of defense, some bacteria and fungi strains are able to metabolize tellurium salts in their reductive metabolism, leading to biologically inert $\mathrm{Te}^{0}$ or tellurolate $\left(\mathrm{Te}^{2-}\right)$, which is methylated to volatile, garlic smelling $\left(\mathrm{H}_{3} \mathrm{C}\right)_{2} \mathrm{Te}$, in such a way that tellurium is eliminated from the medium where the microorganism is. The reduction and methylation of tellurium occur also in mammals including humans. The injection of tellurium salt solutions in animals lead to the formation of $\mathrm{Te}^{0}$ and $\left(\mathrm{H}_{3} \mathrm{C}\right)_{2} \mathrm{Te}$, which are eliminated by breath, urine and sweat (Chasteen and Bentley 2003).

Tellurate $\left(\mathrm{TeO}_{4}^{2-}\right)$ is about 2- to 10 -fold less toxic than tellurite in most organisms studied (Harrison et al. 2004). However, due to its poor solubility in aqueous conditions, very little has been done with this form of tellurium. Finally, as another effect of an inorganic form of tellurium, it has been reported that tellurium tetrachloride is a reversible inhibitor of $\mathrm{Zn}^{2+}$ glicerolphosphocoline coline phosphodiesterase by tellurium tetrachloride (Sok and Kim 1992). This enzyme is found in the nervous system and is related with the myelin basal membrane homeostasis. It should be noted that tellurium tetrachloride readly hydrolyses in water and, because of this, the tellurium specie responsible for the inhibition was not clarified.

Aspects of the effects of selenium and tellurium in microorganisms were recently covered in an excelent review (Zannoni et al. 2008). An interesting application of $\mathrm{TeO}_{3}^{2-}$ consists in its use as an additive to growth media for the selection and identification of various microorganisms, particularly those resistant to tellurite, for almost 90 years. It is often employed in selective media to isolate a wide range of pathogens including: Corynebacterium diphtheriae, Vibrio cholerae (Shimada et al. 1990), Shigella spp. (Rahaman et al. 1986), and verocytotoxigenic $E$. coli $\mathrm{O} 157: \mathrm{H} 7$ (the "hamburger disease" bacterium) (Zadic et al. 1993, Kormutakova et al. 2000). Considerable work has been focused on the pathogenic E. coli $\mathrm{O} 157: \mathrm{H} 7$ since this strain is highly tolerant to metalloid anions. This allows the use of tellurite-enriched media for its identification and isolation. Tellurite is reduced in these strains, resulting in a dark black colony. Tellurite is highlighted as a key selection ingredient (De Boer and Heuvelink 2000) and is also used in media to select Shiga toxin-producing E. coli (STEC) O26 (Hiramatsu et al. 2002). However, a study on E. coli $\mathrm{O} 46$ and $\mathrm{O} 15: \mathrm{H} 7$ strains suggest that there is no correlation between the tellurium resistance and the ability to produce Shiga toxin (Taylor et al. 2002). In addition to E. coli strains, tellurite has been used in selection media for other organisms, including Mycobacterium avium complex (Afghani and Fujiyama 2001), methicillin-resistant Staphylococcus aureus (MSRA) (Zadic et al. 2001), pathogenic Vibrio spp. (Donovan and van Netten 1995). Cefixime-tellurite media has been used for isolating organisms from minced beef (Dogan et al. 2003), rectal swabs of cattle (Yilmaz et al. 2002), raw vegetables (Fujisawa et al. 2002), and sprouts (Fujisawa et al. 2000).

Tellurite and tellurate have also been proposed for use in selective media for identification of fecal Streptococci (Saleh 1980). It is clear that tellurite has proven to be a useful amendment for selection media in clinical laboratory settings and will continue to do so. However, this approach should be used with caution since nonpathogenic strains can acquire tellurite resistance determinants, thereby appearing in many clinical assays as false positives.

A noteworthy possibility of exploring the microorganism tellurium resistance is highlighted if one considers the unique challenges of the use of microorganisms in environmental sciences. The exploitation of microorganisms for the bioremediation of contaminated areas is nowadays of particular interest. The use of antibiotic resistance markers in usual molecular biology techniques may have deleterious consequences in the spread of multi-drug resistance strains. It has been show that the tellurium resistance genes can be used to follow Pseudomonas putida following environmental release for organic degradation (Sanchez-Romero et al. 1998). Tellurite has also been used to detect and quantify the release of Pseudomonas pseudoalcaligenes KF707 in soils for polychlorinated biphenyl (PCB) degradation (Zanaroli et al. 2002). Bacteria can mediate bioremediation of tellurium either through direct sequestration, bioreduction, or biomethylation. In sequestration, bacteria do not biotransform the chalcogen oxyanions into a less toxic compound; the accumulation may occur either through uptake or interaction with surface biomolecules 

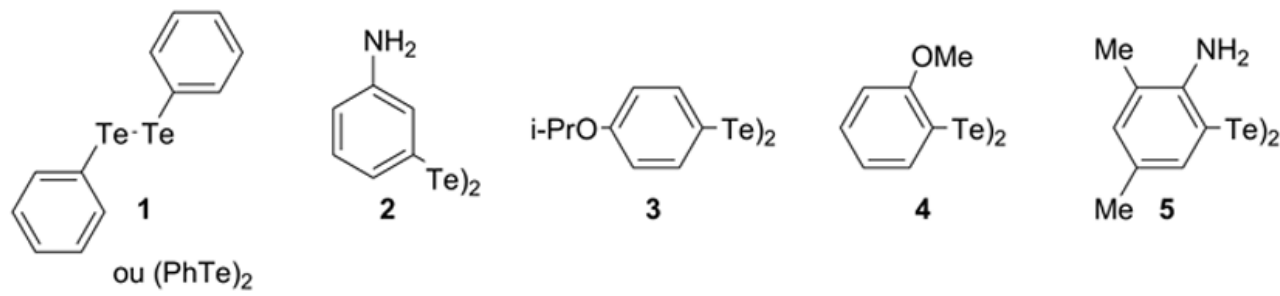

Fig. 1 - Molecular structures of diorgano ditellurides used in toxicological studies.

acting in the form of an ion-exchange matrix. Bioreduction instead reduces the more toxic oxyanion forms to the "non-toxic" $\mathrm{Te}^{0}$. This process usually occurs intracellularly, leading to the precipitation of the metallic form within the cell. Biomethylation leads to volatile methyl derivatives that disperse into the atmosphere. Thus, the chalcogen can travel considerable distances providing detoxification of local contamination sites through dilution by diffusion.

The tellurite resistance determinants kilAtelAB, ter, $\operatorname{teh} A B$, and $\operatorname{ars} A B C$ were investigated for use in tellurite remediation. The use of the plasmid borne tellurite resistance determinant teh $A B$ was found to facilitate the largest amount of uptake of tellurite from the external media (Turner et al. 1994). Highly resistant microbes could also potentially be used for Te bioremediation. Strains of marine purple non-sulfur bacteria with resistance to $5 \mathrm{mM}$ tellurite were found to decrease the concentration of tellurite in the external media 100 -fold and led to accumulation of elemental tellurium deposits in cells (Yamada et al. 1997). The bioreduction of toxic inorganic forms of tellurium may have promising use for aquifer contamination sites and the same techniques are also applicable for other metalloid derivatives as well.

\section{BiologicAl EFFECTS}

OF ORGANOTELLURIUM COMPOUNDS

There are just a few reports on the toxicology of organotellurium compounds. Albeit the organotellurium compounds were considered less toxic than the selenium derivatives (Engman 1985), recent studies indicate the contrary (Nogueira et al. 2004). It must be pointed that research efforts are focused mainly on the effects of diorganoditellurides. The systematic study on the biological effects of different classes of organotellurium compounds is still an open branch of investigation.
Diphenylditelluride, $(\mathrm{PhTeTePh})(\mathbf{1})$ have been extensively used in toxicological studies. The administration of doses of $\mathbf{1}$ to test animals showed an expressive toxicity $-\mathrm{LD}_{50}<1 \mu \mathrm{mol} / \mathrm{kg}$ (rat); $\mathrm{LD}_{50} \approx 150 \mu \mathrm{mol} / \mathrm{kg}$ (mice). Mice survived for $72 \mathrm{~h}$ after the administration of doses of $500 \mu \mathrm{mol} / \mathrm{kg}$ of 1 whereas $75 \%$ of rats treated with doses of $0.75 \mu \mathrm{mol} / \mathrm{kg}$ died. Inasmuch, the administration to rats of shorter dosed of diphenylditelluride $(0.5 \mu \mathrm{mol} / \mathrm{kg})$ showed an increase of alanine and aspartate aminotransferase activities in serum indicative of an induction of alteration in the normal function of liver and kidney of the testing animals (Meotti et al. 2003).

The toxicology of organotellurium compounds have been studied mainly by empirical methods based on the relative toxicity observed in animals, or the evaluation of effects in tissues or by the inhibition of cellular growth (Sailer et al. 2004). For these reasons, Chasteen and coworkers evaluated the toxicity of a series of diaryl ditellurides (2-5, Fig. 1) to HL-60 cells by measuring the induction of apoptosis by cell cytometry (Sailer et al. 2003). The ditellurides showed a meaningful apoptosis induction in doses of $1 \mu \mathrm{M}$, except for the ditelluride 4 which minimal dose was of $10 \mu \mathrm{M}$.

Despite the toxic effects demonstrated for compounds 1-5, applications of other classes of organic tellurium compounds have been studied. Among them, the most thoughtfully described effect is the antioxidant properties of organic tellurides.

GSH acts as a reductor and as substrate of GSH peroxidases (GPx) and transferases. The GPx enzymes contain selenium as selenocysteine at its active site and acts in conjunction with GSH to avoid or minimize oxidative damage in biomolecules. The biochemical function of glutathione peroxidase is to reduce lipid hydroperoxides to their corresponding alcohols and to reduce free hydro- 
gen peroxide to water. The GPx catalytic selenol (En$\mathrm{zSeOH})$ is oxidized by hydroperoxides $(\mathrm{ROOH})$ to selenilic acid (EnzSeOH), leading also to the reduced form of the hydroperoxide (ROH). The oxidized GPx (EnzSeOH) reacts with GSH, leading to the mixed dichalcogenide (EnzSeSG) which reacts with another GSH molecule, forming oxidized gluthathione (GSSG) and restoring the catalytic active GPx (Fig. 2).

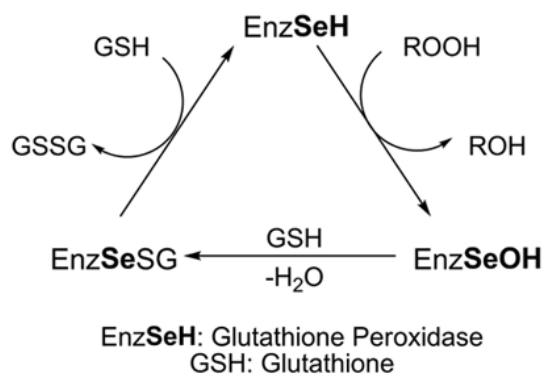

Fig. 2 - Catalytic cycle of gluthathione peroxidases showing the reduction of an organic hydroperoxide.

Since this process is related to the chemical reactivity of the catalytic selenium, the exploitation of organoselenides and organotellurides as GPx mimetics are well covered in the literature. Due to the fundamental relevance of this process in aging and the potential use of antioxidants as prospective drugs for oxidative stress-related diseases, several studies have been undertaken with selenium compounds that act as mimics of GPx enzymes such as aromatic selenides and diselenides, selenium heterocycles containing Se-N moiety, the artificial selenosubtilysin, and selena-peptides among other selenium derivatives (Mugesh et al. 2001). The substitution of selenium for tellurium in arylic derivatives greatly improves the antioxidant activity. Andersson and coworkers (1994) described the antioxidant activity of organotellurium compounds in vitro. It was observed the improvement on efficacy of tellurides $\mathbf{6}$ and 7 in the inhibition of lipid peroxidation of cells induced by oxidative conditions (Fig. 3).
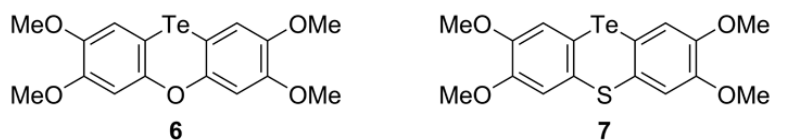

Fig. 3 - First organotellurium compounds used as antioxidants.
After this first report, the antioxidant activity of a series of arylic tellurides 8a-k was compared with the selenium heterocycle Ebselen, the first selenium compound which the GPx-like activity was demonstrated in chemical and biochemical systems (Fig. 4). The used diaryltellurides were found to efficiently inhibit peroxidation in rat hepatocytes, rat liver microssomes and an organic solution of phosphatidylcholine (Andersson et al. 1994).
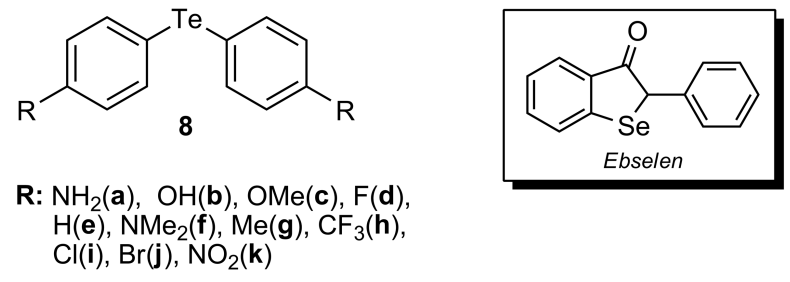

Fig. 4-Arylic tellurides used in the first demonstration of their GPx-like activity.

The mechanism of the thiol-peroxidase activity of organotellurides was studied further by Engman and coworkers (1994). It was proposed that the organotelluroxide in the hydrate form reacts with thiols, producing disulfides and regenerating the initial diorganotelluride as shown in Figure 5.

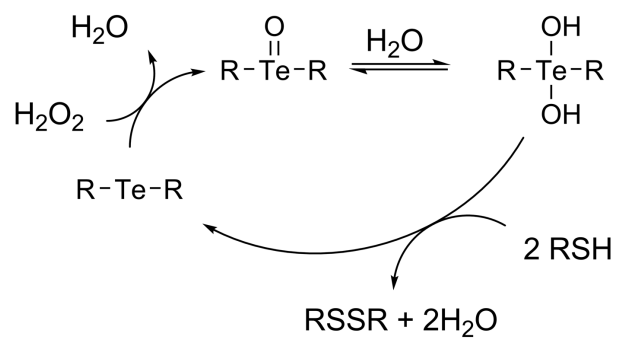

Fig. 5 - Proposed mechanism of the GPx-like activity of diorganotellurides (adapted from Engman et al. 1994).

From these initial studies, several groups have been reporting the antioxidant activity of several organic tellurides. A common observed feature consists in the great antioxidant efficacy of tellurium derivatives in comparison to sulfur or selenium analogues. It is noteworthy that diaryl tellurides inhibit lipid peroxidation much longer than conventional antioxidants, indicating an autocatalytic mechanism of antioxidant activity (Engman et al. 1995). The antioxidant properties of organotel- 
lurium compounds were also demonstrated in complex cellular systems, in which the abrogation of radical chain reactions and the decomposition of peroxides were observed (Wieslander et al. 1998). These make this class of organotellurium compounds promising candidates for the use in the developing antioxidant therapies. As an example, the inhibition of thioredoxin/thioredoxin reductase system (TrxR) and cancer cell growth by antioxidant organotellurium compounds structurally related to vitamin E was reported (Engman et al. 2003). TrxR system is a promising redox target for cancer therapy (Urig and Becker 2006).

Another class of organotellurium compounds which showed antioxidant activity is the diorgano ditellurides (Fig. 6). Tellurium dichalcogenides are more efficient antioxidants than selenium counterparts. Engman and coworkers (1992) proposed a mechanism for the thiolperoxidase activity performing a series of elegant NMR experiments. The ditellurides which presents in its structure coordinating nitrogen groups exhibits a strong secondary interaction between tellurium and nitrogen atoms. Interestingly, it was observed an inverse linear

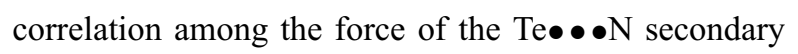
interaction and the GPx-like activity: as the secondary interaction gets stronger, the GPx-like activity diminishes.

Furthermore, more complex organotellurium compounds with antioxidant activities were also described, being the case of semisynthetic tellurosubtilisin (Mao et al. 2005), dendrimeric organotellurides (Francavilla et al. 2001, Ahsan et al. 2003); and tellurium-based polymeric surfactants. The thiol-peroxidase activity of these systems was more active than the previously described semi-synthetic tellurosubtilisin (Huang et al. 2006). In a more sophisticated report, a nanoenzyme model with glutathione peroxidase-like active site was built on polystyrene nanoparticle via microemulsion polymerization (Huang et al. 2008). The nanoenzyme mimics showed to be highly efficient, but the major achievement was the demonstration that polymeric nanoparticles can be developed as excellent models for combining most of catalytic factors of enzyme into one scaffold.

Organotellurium compounds also have found applications in Photodynamic therapy (PDT). PDT has been developed as an alternative cancer therapy over the last thirty-five years and had acquired regulatory approval in several countries for carcinomas of the lung, digestive tract, and genitourinary tract. PDT cancer treatment is also in development for head, neck and pancreas carcinomas. The principle of this therapy is based in the use of a sensitizer agent which is capable to interact with light producing cytotoxic species or a cytotoxic reaction in tumoral carcinoma, typically singlet oxygen $\left({ }^{1} \mathrm{O}_{2}\right)$ or superoxide from molecular oxygen (Leonard et al. 1999). The sensitizer agent is generally porphirins, phthalocyanines or dyes, and may ideally present a preferential interaction with tumoral cells. Detty and coworkers reported the in vitro production of ${ }^{1} \mathrm{O}_{2}$ by the irradiation of an oxygen saturated solution of chalcogen-based dyes 14 shown in Figure 7 (Detty et al. 1990). In this first report, a series of chalcogena-pyrilium salts were prepared and characterized as inhibitors of cytochrome c oxidase in tumoral cells. The damage induced by $\mathbf{9 c}$ was verified by pronunciated morphological changes in mitochondria from human glyoma cells. This report is noteworthy because it compares all possible chalcogen derivatives and it was verified that the selenium and tellurium derivatives were more efficient sensitizers.

More recently, Brennan and coworkers (2002) developed a novel class of chalcogena-pyrilium dyes (10), more resistant to hydrolysis and structurally related to the tio-pyrilium salt AA1, which has a defined and specific action on mitochondria (Fig. 8).

The antitumoral activity of the of the thiatellurocarbocyanine iodide 11 (Fig. 9) was found from a screening of 1000 lipophilic cationic compounds demonstrated by Sun and coworkers (1996). Lipophilic cationic compounds were found to be a class of antitumoral agents due to its selective localization, accumulation and retention within the mitochondria of certain tumoral cells (Sun et al. 1996). Certain selectivity toward tumoral cells was observed in vitro assays, in which 11 was 64fold more toxic to the CX-1 carcinoma cells in comparison to the epithelial CV-1 cell line. Regarding the in vivo studies, the administration of $\mathbf{1 1}$ significantly prolonged the survival of mice implanted with tumors. The action of $\mathbf{1 1}$ on mitochondria was attributed by similarity of the well-known effects of similar compounds like a thiopyrilium salt AA1 (Fig. 8), which is a potent inhibitor of mitochondrial ATP hydrolysis (Davis et al. 1985). 
<smiles>[R]c1ccc2c([R])cccc2c1[14CH3]</smiles><smiles>Brc1cccc2ccccc12</smiles>

R: $\mathrm{H}, \mathrm{CH}_{3}$<smiles>CNc1cccc2cccc([14CH3])c12</smiles><smiles>CCCCCCP(=O)(O)c1ccccc1C(=O)Nc1ccccc1</smiles><smiles>[Y60]c1ccccc1C1=NC([R])([R])CO1</smiles>

$\mathbf{R}=\mathbf{R}_{\mathbf{1}}: \mathrm{H}, \mathrm{Me}$

R: $\mathrm{H}, \mathbf{R}_{\mathbf{1}}$ : Et

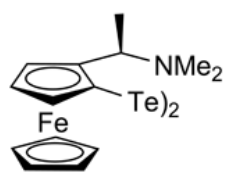

Fig. 6 - Diorganil ditellurides with mimetic GPx activity.<smiles>[H][Y]1c(C(C)(C)C)cc(=CC=Cc2cc(C(C)(C)C)[Y]([2H])c(C(C)(C)C)c2)cc1C(C)(C)C</smiles>

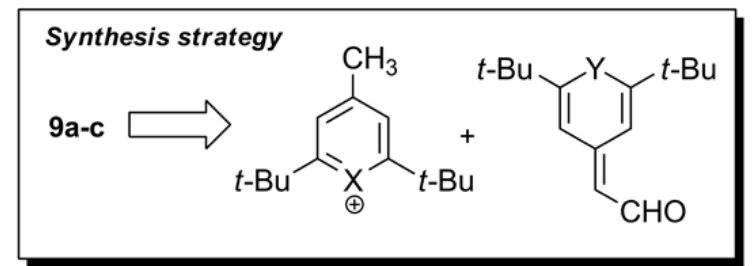

9a, $X=T e, Y=O$

9b, $X=T e, Y=S$

9c, $X=\mathrm{Te}, Y=\mathrm{Se}$

Fig. 7 - Molecular structure of chalcogena-pyrilium salts and the main strategy for its preparation.<smiles>[R]c1ccc(-c2cc(-c3ccc([R])cc3)[o+]c(-c3ccc([R])cc3)c2)cc1</smiles><smiles></smiles>

10a, $\mathrm{R}=\mathrm{NMe}_{2}, \mathrm{R}_{1}=\mathrm{R}_{2}=\mathrm{H}, \mathrm{A}=\mathrm{BF}_{4}$ 10b, $R=R_{1}=R_{2}=\mathrm{NMe}_{2}, A=\mathrm{Cl}$

10c, $\mathrm{R}=\mathrm{NMe}_{2}, \mathrm{R}_{1}=\mathrm{H}, \mathrm{R}_{2}=\mathrm{NH}_{2}, \mathrm{~A}=\mathrm{Cl}$

10d, $R=\mathrm{NMe}_{2}, \mathrm{R}_{1}=\mathrm{R}_{2}=\mathrm{NH}_{2}, A=\mathrm{Cl}$

10e, $\mathrm{R}=\mathrm{N}$-morfolinyl, $\mathrm{R}_{1}=\mathrm{R}_{2}=\mathrm{NH}_{2}, \mathrm{~A}=\mathrm{Cl}$

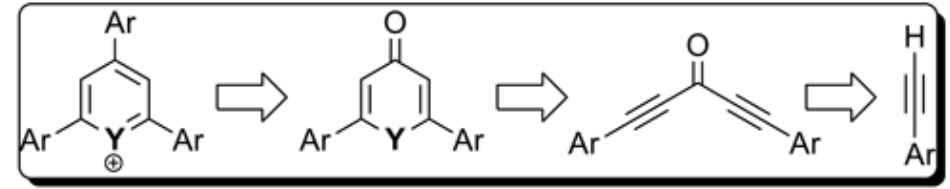

Fig. 8 - Tellura-pyrilium salts related to AA1 and the synthetic approach to their access. 


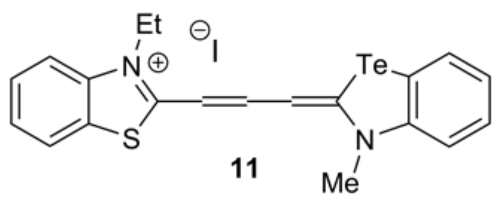

Fig. 9 - Molecular structure of the thiatelluracarbocyanine iodide 11.

The effects of organotellurium(II) compounds were described above. Another important group of organotellurium compounds, the hypervalent organotellurium compounds (organotelluranes), with described and nascent applications, is described below. The biological applications of organotelluranes are far less studied than those of organotellurium(II) compounds.

The antihelminic of four organotelluranes (13-17) was demonstrated against Trichinella spiralis infected mice (Ordyntseva et al. 1988). The organotelluranes 13-15 were prepared by the reaction of the aryllithium reagent 12 and $\mathrm{TeI}_{2}$ followed by the oxidation of the obtained organotellurides with chlorine or bromine. The fourth organotellurane was prepared by the reaction of the organotelluride $\mathbf{1 6}$ with phosphorous oxychloride, followed by the sequence of reduction and oxidation with bromine which lead to $\mathbf{1 7}$ (Scheme 1). The effect of these compounds was compared with mebedazol; compound 15 did not show any activity, whereas 13 and 14 were less effective than mebedazol; $\mathbf{1 7}$ showed similar activity.

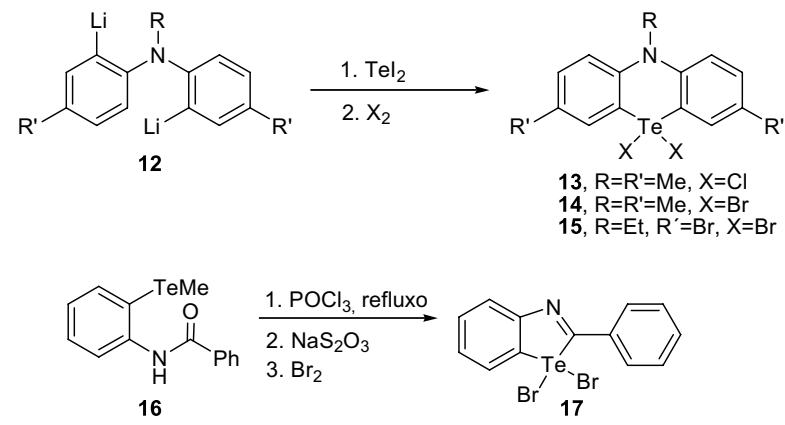

Scheme 1 - Synthesis of organotelluranes with anti-helmintic activity.

Soni and coworkers (2005) recently showed the antibacterial activity of a series of unsymmetrical diorganyltellurium dichlorides (18-22) (Fig. 10). It has been found the antibacterial effect against gram-positive (Baclilus subtilis, Staphylococcus aureus) and gram-negative bacteria (Escherichia coli, Pseudomonas aeruginosa and Salmonella sp.). All tested compounds presented effect against gram-negative bacteria, and the 2- naphtyl series (20-22) were most effective, but mechanism of this effect was not demonstrated.<smiles>[R]c1ccc([Te](Cl)(Cl)CC(=O)c2ccccc2)cc1[R]</smiles>

$\mathrm{R}_{1}=\mathrm{H}, \mathrm{R}_{2}=\mathrm{OH}(18)$

$\mathrm{R}_{1}=\mathrm{CH}_{3}, \mathrm{R}_{2}=\mathrm{OH}$ (19)

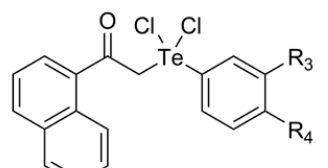

$\mathrm{R}_{3}=\mathrm{H}, \mathrm{R}_{4}=\mathrm{OCH}_{3}(21)$

$\mathrm{R}_{3}=\mathrm{CH}_{3}, \mathrm{R}_{4}=\mathrm{OH}(22)$
$\mathrm{R}_{3}=\mathrm{H}, \mathrm{R}_{4}=\mathrm{OH}(20)$

Fig. 10 - Organotelluranes with gram-negative antibacterial effect.

Inorganic and organic tellurium derivatives are highly toxic for the central nervous system of rodents (Maciel et al. 2000). Compounds 23, 24, and 25 (Fig. 11) are potent inhibitors of either purified squalene monooxigenase (Laden and Porter 2001) and also for its activity in cells (Goodrum 1998), causing a dramatic reduction in cholesterol biosynthesis and leading to the degradation of myelin and further demyelinization of peripheral nerves. The inactivation of squalene monooxigenase occurs by the interaction of the telluranes and a pair of vicinal thiols from the catalytic cysteine in the enzyme. Dimethyltellurium dichloride $\mathbf{2 3}$ is the most potent inhibitor of this enzyme, and its effects on nerve cells are very similar to those observed in the $\mathrm{Te}^{0}$-induced neuropathy.

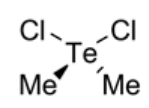

23

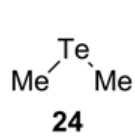

24

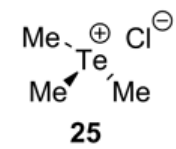

25
Fig. 11 - Tellurium-based inhibitors of cholesterol biosynthesis.

Finally, organotelluranes have been studied as protease inhibitors. The first description of this effect was reported for inorganic telluranes (Albeck et al. 1998). In this first seminal report, tellurium(IV), tellurium(VI) compounds and the effect on the activity of the four main classes of proteases were studied. It has been found that just the inorganic tellurium(IV) compounds exhibited a specific inhibitory activity towards cysteine proteases papain and cathepsin B from bovine spleen. More recently, an inorganic tellurane obtained from tartaric acid, named SAS, was also reported to be a more potent inhibitor of papain and cathepsin B than AS-101 (Yosef et al. 2007) (Fig. 12). All of these compounds (except $\mathrm{TeO}_{2}$ ) have been erroneously classified as organotellurium compounds, but since none of those possess 
any formal carbon-tellurium bond, it should be correctly classified as inorganic tellurium compounds.

In comparison to those and other inorganic telluranes, the organotelluranes has a particular advantage. Once the inorganic ones are limited to the availability of the ligand, the organic ones can be obtained by the oxidation of every organotellurium(II) compound which can have a plethora of structural motifs. Taking this into account, a small set of organotelluranes was evaluated as inhibitors of recombinant human cathepsin B (Cunha et al. 2005). It was therefore observed that the organotelluranes were potent inactivators of cathepsin B (Fig. 13). The inactivation of cathepsin B was time- and concentration- dependent and involves the modification of enzyme's catalytic thiol. The most interesting feature of the organotellurane inhibition consists in the recovery of the enzyme activity by the use of reducing agents such as dithiothreitol (DTT). Docking studies have been carried out using these and other organotellurium compounds (Cunha et al. 2006). It is anticipated that the information collected from this studies may be useful to plan specific and more potent derivatives.

A larger collection of organotelluranes was further assayed with recombinant cathepsins $\mathrm{B}, \mathrm{L}, \mathrm{S}$ and $\mathrm{K}$ to seek for selectivity aspects on the inhibition of closely related cysteine proteases (R.L.O.R. Cunha, I.E. Gouveia et al., unpublished data). It was observed interesting inhibition profiles using these cathepsins which revealed selective inactivation of each cathepsin with a different organotelluranes, especially for cathepsins $\mathrm{S}$ and $\mathrm{K}$. Since the effect upon a biological target was established, further exploration of the effects of organotelluranes, on more complex models where the activity of cysteine proteases is associated, has been explored. As examples, it was described the effect of organotelluranes in angiogenesis and the cytotoxicity on several cancer cell lineages (R.L.O.R. Cunha, T. Paschoalin et al., unpublished data); the induction of apoptosis in human HL-60 cells (Abondanza et al. 2008). The protective effect of an organotelluroxetane in an animal model of epilepsy was also demonstrated. The pre-administration of the organotelluranes avoided the establishment of the status epilepticus in rats (Persike et al. 2008); as caspases were described to be involved in epilepsy, the inactivation of recombinant caspase- 3 and caspase- 8 was demonstrated with the organotelluxetane, anionic organotelluranes and AS-101. Once again, the organotelluranes were better inactivators in comparison to AS-101. Finally, the effect of organotelluranes in isolated mitochondria was investigated (Pessoto et al. 2007). It was found that these compounds induce the formation of a transition pore in mitochondria inner membrane (but avoids the oxidative damage which usually arises); this was explained by the formation of organotellurium(II) species from the interaction of the organotelluranes with membrane proteins.

\section{CONCLUSIONS}

Albeit the conventional prejudice concerning tellurium and its compounds, the role of tellurium at the stage of biology is at its beginning. Tellurium compounds have a particular chemistry with thiol which is related to many of the biological effects observed so far. Besides of this, there are a lot of information and possible new concepts waiting to be addressed to allow a rational development of the uses of tellurium compounds in biology and medicine. In particular, the fate of organotellurium(II) in biological media, the reactivity of tellurium compounds towards bionucleophiles and a broad knowledge on other possible targets must be clarified before further developments.

\section{ACKNOWLEDGMENTS}

Fundação de Amparo à Pesquisa do Estado de São Paulo (FAPESP), Conselho Nacional de Desenvolvimento Científico e Tecnológico (CNPq) and Coordenação de Aperfeiçoamento de Pessoal de Nível Superior (CAPES) are acknowledged for research grants and scholarships. RLORC thanks to FAPESP for a post-doctoral scholarship (process no. 04/14426-0).

\section{RESUMO}

O telúrio é um elemento não-essencial raro que vem sendo considerado tóxico, e o seu papel biológico é ainda pouco esclarecido. Apesar disso, os efeitos biológicos do telúrio elementar e de alguns derivados inorgânicos e orgânicos que têm sido estudados revelam um conjunto de aplicações diversificadas interessantes e promissoras. Como exemplo, pode-se destacar os usos de teluritos e teluratos de metais alcalinos em microbiologia, o efeito antioxidante de teluretos e diteluretos orgânicos, os efeitos imunomodulatórios e a diversidade de usos cor- 


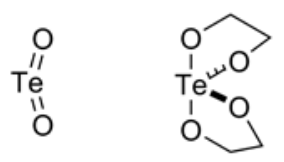<smiles>O=C(O)CC1(C(=O)O)CC(=O)O[Te]2(CC(=O)O)OC(=O)CC1(C(=O)O)O2</smiles><smiles>NCOP(Cl)(Cl)(Cl)Cl</smiles>

AS-101

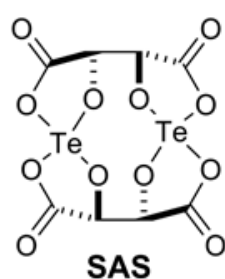

Fig. 12 - Inorganic telluranes as specific cysteine protease inhibitors.

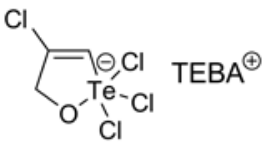

$k_{2}=6000 \mathrm{M}^{-1} \mathrm{~s}^{-1}$<smiles>OC(C(=CCl)[Ge](Cl)(Cl)Cl)c1ccccc1</smiles>

$k_{2}=12000 \mathrm{M}^{-1} \mathrm{~s}^{-1}$<smiles>COc1ccc([Te]2(Cl)OC3(CCCCC3)/C2=C\Cl)cc1</smiles>

$k_{2}=36000 \mathrm{M}^{-1} \mathrm{~s}^{-1}$<smiles>COc1ccccc1C(=O)C=C(c1ccccc1OC)c1ccccc1C(F)(F)Cl</smiles>

$k_{2}=15000 \mathrm{M}^{-1} \mathrm{~s}^{-1}$

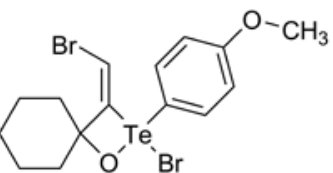

$k_{2}=7700 \mathrm{M}^{-1} \mathrm{~s}^{-1}$

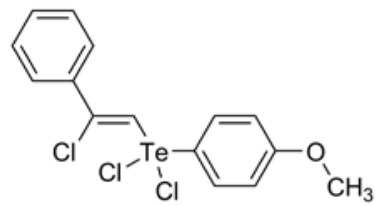

$k_{2}=7900 \mathrm{M}^{-1} \mathrm{~s}^{-1}$<smiles>COc1ccc(C2(Cl)OC3(CCCCCC3)C2=CCl)cc1</smiles>

$k_{2}=1600 \mathrm{M}^{-1} \mathrm{~s}^{-1}$

Fig. 13 - Organotelluranes with potent irreversible inactivation of recombinant human cathepsin B, above the molecular structures the secondorder inactivation rate constants determined for each compound is indicated.

relacionados a este efeito de uma telurana inorgânica denominada AS-101. Ademais, as aplicações de teluranas orgânicas (organoteluranas) como inibidoras de proteases e as aplicações em modelos de doenças compõem a mais recente contribuição ao cenário dos efeitos e aplicações biológicas do telúrio e seus compostos discutidas neste manuscrito.

Palavras-chave: antitumorais, aplicações biológicas, enzimas inibidoras, compostos orgânicos de telúrio, proteases, telúrio.

\section{REFERENCES}

Abondanza TS, Oliveira CR, Barbosa CMV, PereiRa FEG, Cunha Rlor, Caires ACF, Comasseto JV, Queiroz MLS, VALAdares MC AND BincoletTO C. 2008. Bcl-2 expression and apoptosis induction in human HL-60 leukaemic cells treated with a novel organotellurium(IV) compound RT-04. Food Chem Toxicol 46: 2540-2445.

AfGHANi B AND FujIYAMA D. 2001. Use of potassium tellurite for rapid-drug susceptibility testing of Mycobacterium avium complex. J Invest Med 49: 292-296.
Ahsan K, Drake MD, Higgs De, Wojciechowski AL, Tse BN, Bateman MA, You Y and Detty MR. 2003. Dendrimeric Organotelluride Catalysts for the Activation of Hydrogen Peroxide. Improved Catalytic Activity through Statistical and Stereoelectronic Effects. Organometallics 22: 2883-2890.

Albeck A, Weitman H, SRedni B and Albeck M. 1998. Tellurium compounds: selective inhibition of cysteine protease and model reaction with thiols. Inorg Chem 37: 1704-1712.

Andersson CM, Brattsand R, Hallberg A, Engman L, Persson J, Moldéus P And Cotgreave I. 1994. Diaryl tellurides as inhibitors of lipid peroxidation in biological and chemical systems. Free Radic Res 20: 401410 .

Asakura T, Shibutani Y, Reilly MP and DeMeio RH. 1984. Antisickling effect of tellurite: a potent membraneacting agent in vitro. Blood 64: 305-307.

Boles JO, Lebioda L, Dunlap RB AND Odom JD. 1995. Telluromethionine in structural biochemistry. Saas Bull. Biochem Biotechnol 8: 29-34. 
Bragnall KW. 1966. The Chemistry of Selenium, Tellurium, and Polonium. Elsevier Publishing Co.: London.

Brennan NK, Hall JP, DaVies SR, Gollnick SO, Oseroff AR, Gibson SL, Hilf R And DetTy MR. 2002. In vitro photodynamic properties of chalcogenopyrylium analogues of the thiopyrylium antitumor agent AA1. J Med Chem 45: 5123-5135.

Brodsky M, Yosef S, Galit R, Albeck M, Longo DL, Albeck A And Sredni B. 2007. The synthetic tellurium compound, AS101, is a novel inhibitor of IL1beta converting enzyme. J Interferon Cytokine Res 27: 453-462.

Budisa N, Steipe B, Demange P, Eckerskorn C, Kellermann J AND Huber R. 1995. High-level biosynthetic substitution of methionine in proteins by its analogs 2-aminohexanoic acid, selenomethionine, telluromethionine and ethionine in Escherichia coli. Eur J Biochem 230: 788-796.

Budisa N, Karnbrock W, Steinbacher S, Humm A, Prade L, Neuefeind T, Moroder L and Huber R. 1997. Bioincorporation of telluromethionine into proteins: a promising new approach for X-ray structure analysis of proteins. J Mol Biol 270: 616-623.

Chambers I, Frampton J, Goldfarb P, AfFara N, MCBAIN W AND HARRISON PR. 1986. The structure of the mouse glutathione peroxidase gene: the selenocysteine in the active site is encoded by the 'termination' codon, TGA. EMBO J 6: 1221-1227.

Chasteen TG and Bentley R. 2003. Biomethylation of selenium and tellurium: microorganisms and plants. Chem Rev 103: 1-26.

Comasseto JV, Cunha RLOR And Clososki GC. 2007. Cap. 9.13. Tellurium. In: Robert Crabtree; MiKe Mingos. (Org.). Comprehensive Organometallic Chemistry III (COMC-3). Elsevier: New York, 2007, v. 9, p. 587-648.

CoOper WC. 1971. Tellurium. Van Nostrand Reinhod Co.: New York.

Cunha Rlor, Urano ME, Chagas JR, Almeida PC, Bincoletto C, Tersariol ILS AND Comasseto JV. 2005. Tellurium-based cysteine protease inhibitors: evaluation of novel organotellurium(IV) compounds as inhibitors of human cathepsin B. Bioorg Med Chem Lett 15: 755-760.

CUNHA RLOR, ZuKERMAN-SCHPECTOR J, CARACELli I AND COMASSETO JV. 2006. Revisiting the addition reaction of TeCl4 to alkynes: The crystal structure and docking studies of 1-chloro-2-trichlorotelluro-3-phenyl-propen-2ol. J Organomet Chem 691: 4807-4815.
Davis S, Weiss MJ, Wong JR, LAMPIDIS TJ AND ChEN LB. 1985. Mitochondrial and plasma membrane potentials cause unusual accumulation and retention of rhodamine 123 by human breast adenocarcinoma-derived MCF-7 cells. J Biol Chem 260: 13844-13850.

De Boer E And Heuvelink AE. 2000. Methods for the detection and isolation of Shiga toxin-producing Escherichia coli. Symp Ser Soc Appl Microbiol 29: 133S$143 \mathrm{~S}$.

De Meio RH And HenriQues FC. 1947. Tellurium IV, excretion and distribution in tissues studied with a radioactive isotope. J Biol Chem 169: 609-623.

Detty MR, Merkel PB, Hilf R, Gibson SL and PoWERS SK. 1990. Chalcogenapyrylium dyes as photochemotherapeutic agents. 2. Tumor uptake, mitochondrial targeting, and singlet-oxygen-induced inhibition of cytochrome c oxidase. J Med Chem 33: 1108-1116.

Deuticke B, Lütkemeier P And Poser B. 1992. Tellurite-induced damage of the erythrocyte membrane. Manifestations and mechanisms. Biochim Biophys Acta 1109: 97-107.

Dogan HB, Kuleasan H, Cakir I And Halkman AK. 2003. Evaluation of increased incubation temperature and cefixime-tellurite treatment for the isolation of Escherichia coli O157:H7 from minced beef. Int J Food Microbiol 87: 29-34.

Donovan TJ AND VAN NetTen P. 1995. Culture media for the isolation and enumeration of pathogenic Vibrio species in foods and environmental samples. Int J Food Microbiol 26: 77-91.

ENGMAN L. 1985. Synthetic applications of organotellurium compounds. Acc Chem Res 18: 274-279.

Engman L, Stern D, Cotgreave IA And Andersson CM. 1992. Thiol peroxidase activity of diaryl ditellurides as determined by a $1 \mathrm{H}$ NMR method. J Am Chem Soc 114: 9737-9743.

Engman L, Stern D, Pelcman M and Andersson CM. 1994. Thiol peroxidase acitivity of diorganotellurides. J Org Chem 59: 1973-1979.

Engman L, Persson J, Vessman K, Ekström M, BerGLUND M AND ANDERSSON CM. 1995. Organotellurium compounds as efficient retarders of lipid peroxidation in methanol. Free Radic Biol Med 19: 441-452.

Engman L, Al-Maharik N, McNaughton M, BirMINGHAM A AND Powis G. 2003. Thioredoxin reductase and cancer cell growth inhibition by organotellurium antioxidants. Anti-Cancer Drugs 14: 153-161. 
FISCHER W. 2001. A second note on the term "chalcogen". J Chem Educ 78: 1333.

FLEMING A. 1932. On the specific antibacterial properties of penicillin and potassium tellurite. J Pathol Bacteria 35: 831-842.

FLEMING A AND Young MY 1940. The inhibitory action of potassium tellurite on coliform bacteria. J Pathol Bacteriol 51: $29-35$.

FrancaVilla, C, Drake MD, Bright FV and Detty MR. 2001. Dendrimeric Organochalcogen Catalysts for the Activation of Hydrogen Peroxide: Improved Catalytic Activity through Statistical Effects and Cooperativity in Successive Generations. J Am Chem Soc 123: 57-67.

Fujisawa T, SATA S, Aikawa K, TAKahashi T, YamaI S AND SHIMADA T. 2000. Modification of sorbitol MacConkey medium containing cefixime and tellurite for isolation of Escherichia coli $\mathrm{O} 157: \mathrm{H} 7$ from radish sprouts. Appl Environ Microbiol 66: 3117-3128.

Fujisawa T, Sata S, Aikawa K, Takahashi T, Yamai S AND SHIMADA T. 2002. Evaluation of sorbitol-salicin MacConkey medium containing cefixime and tellurite (CT-SSMAC medium) for isolation of Escherichia coli O157:H7 from raw vegetables. Int J Food Microbiol 74: 161-163.

GOODRUM JF. 1998. Role of organotellurium compounds in neuropathy. Neurochem Res 23: 1313-1319.

Goulle' JP, Mahieu L, Castermant J, Neveu N, Bonneau L, Laine' G, Bouige D AND LACRoix C. 2005. Metal and metalloid multi-elementary ICP-MS validation in whole blood, plasma, urine and hair. Forensic Sci Int 153: 39-44.

Guest I AND UetRecht J. 2001. Bone marrow stem cell protection from chemotherapy by low molecular weight compounds. Exp Hematol 29: 123-137.

GUPTA N AND PORTER TD. 2002. Inhibition of human squalene monooxigenase by selenium compounds. J Biochem Mol Toxicol 16: 18-23.

Harrison JJ, Ceri H, Stremick CA ANd Turner RJ. 2004. Biofilm susceptibility to metal toxicity. Environ Microbiol 6: 1220-1227.

HatField DL AND GLadyshev VN. 2002. How selenium has altered our understanding of the genetic code. Mol Cell Biol 22: 3565-3576.

Hiramatsu R, Matsumoto M, Miwa Y, Suzuki Y, SAITO M AND MIYAZAKI Y. 2002. Characterization of Shiga toxin-producing Escherichia coli O26 strains and establishment of selective isolation media for these strains. J Clin Microbiol 40: 922-925.
Huang X, Dong Z, Liu J, Mao S, Luo G and Shen J. 2006. Tellurium-Based Polymeric Surfactants as a Novel Seleno-Enzyme Model with High Activity. Macromol Rapid Commun 27: 2101-2106.

Huang X, LiU Y, Liang K, TAng Y and LiU J. 2008. Construction of the active site of gluthathione peroxidase on polymer-based nanoparticles. Biomacromolecules 9: 1467-1473.

JACOBS JL. 1989. Immunologic developments in AIDS. Year Immunol 4: 276-285.

Klotz LO, KRoncke KD, Buchczyk DP And Sies H. 2003. Role of copper, zinc, selenium and tellurium in the cellular defense against oxidative and nitrosative stress. J Nutr 133: 1448S-1451S.

Kormutakova R, KluCAR L AND TURna J. 2000. DNA sequence analysis of the tellurite-resistance determinant from clinical strain of Escherichia coli and identification of essential genes. BioMetals 13: 135-139.

LADEN BP AND PORTER TD. 2001. Inhibition of human squalene monooxygenase by tellurium compounds: evidence of interaction with vicinal sulfhydryls. J Lipid Res 42: $235-240$.

Leonard KA, Nelen MI, Simard TP, Davies SR, Gollnick SO, Oseroff AR, Gibson SL, Hilf R, Chen LB AND DetTy MR. 1999. Synthesis and evaluation of chalcogenopyrylium dyes as potential sensitizers for the photodynamic therapy of cancer. J Med Chem 42: 3953-3964.

Maciel EN, Bolzan RC, Braga AL and Rocha JB. 2000. Diphenyl diselenide and diphenyl ditelluride differentially affect delta-aminolevulinate dehydratase from liver, kidney, and brain of mice. J Biochem Mol Toxicol 6: 310-319.

Mao SZ, Dong ZY, LiU JQ, Li XQ, LiU XM, LuO GM AND SHEN JC. 2005. Semisynthethic tellurosubtilisin with gluthathione peroxidase activity. J Am Chem Soc 127: 11588-11589.

Meotti FC, Borges VC, Zeni G, Rocha JB and NoGUEIRA CW. 2003. Potential renal and hepatic toxicity of diphenyl diselenide, diphenyl ditelluride and Ebselen for rats and mice. Toxicol Lett 143: 9-16.

MORODER L. 2005. Isosteric replacement of sulfur with other chalcogens in peptides and proteins. J Pept Sci 11: 187214.

Mugesh G, Du Mont WW and Sies H. 2001. Chemistry of biologically important synthethic organoselenium compounds. Chem Rev 101: 2125-2179. 
Mugesh G, Panda A, Kumar S, Apte SD, Singh HB AND BUTCHER RJ. 2002. Intramolecularly Coordinated Diorganyl Ditellurides: Thiol Peroxidase-like Antioxidants. Organometallics 21: 884-892.

Nogueira CW, Zeni G And Rocha JB. 2004. Organoselenium and organotellurium compounds: toxicology and pharmacology. Chem Rev 104: 6255-6285.

OKUN E ET AL. 2007a. The organotellurium compound ammonium trichloro(dioxoethylene-o,o')tellurate reacts with homocysteine to form homocystine and decreases homocysteine levels in hyperhomocysteinemic mice. FEBS J 274: 3159-3170.

Okun E, Arumugam TV, Tang SC, Gleichmann M, Albeck M, SRedni B And Mattson MP. 2007b. The organotellurium compound ammonium trichloro(dioxoethylene-0,0') tellurate enhances neuronal survival and improves functional outcome in an ischemic stroke model in mice. J Neurochem 102: 1232-1241.

Ordyntseva AP, Sivovolsva ID, ABAKAROV GM AND SABEKOVA EI. 1988. Vermicidal activity of organotellurium agents. Khim -Farm Zh 22: 1098-1100.

Persike DS, Cunha Rlor, Juliano L, Silva IR, Rosim FE, Vignolli T, Dona F, CaValheiro EA AND FERnANDES MJS. 2008. Protective effect of the organotellurane RT-07 in pilocarpine-induced status epilepticus. Neurobiol Dis 31: 120-126.

Pessoto FS, Faria PA, Cunha RLOR, Comasseto JV, RODRIGUES T AND NANTES IL. 2007. Organotelluranepromoted mitochondrial permeability transition concomitant with membrane lipid protection against oxidation. Chem Res Toxicol 20: 1453-1461.

Rahaman MM, Morshed MG, Sultanul Aziz KM AND MUNSHI MM. 1986. Improved medium for isolating Shigella. Lancet 1: 271-272.

RAMADAN SE, RAZAK AA, RAGAB AM AND EL-MELEIGY M. 1989. Incorporation of tellurium into amino acids and proteins in a tellurium-tolerant fungi. Biol Trace Elem Res 20: 225-232.

SADEH R. 1987. Biological and biochemical aspects of tellurium derivatives. In: PATAI S (Ed), The Chemistry of Organic Selenium and Tellurium Compounds. J Wiley \& Sons, Chichester 2: 367-376.

SAiler BL, Liles N, Dickerson S AND Chasteen TG. 2003. Cytometric determination of novel organotellurium compound toxicity in a promyelocytic (HL-60) cell line. Arch Toxicol 77: 30-36.

Sailer BL, Liles N, Dickerson S, Sumners S AND Chasteen TG. 2004. Organotellurium compound toxic- ity in a promyelocytic cell line compared to non-telluriumcontaining organic analog. Toxicol in vitro 18: 475-482.

SALEH FA. 1980. Selective media and faecal streptococci recovery: a review. Zentralbl Bakteriol Naturwiss 135: 130-144.

SANCHEZ-ROMERO JM, DIAZ-OREJAS R AND DE LORENZO V. 1998. Resistance to tellurite as a selection marker for genetic manipulations of Pseudomonas strains. Appl Environ Microbiol 64: 4040-4046.

SCHWARZ K AND FolTz CM. 1957. Selenium as an integral part of factor 3 against dietary necrotic liver degeneration. J Am Chem Soc 79: 3292-3293.

Shimada T, Sakazaki R, Fujimura S, Niwano K, MishinA M AND TAKIZAWA K 1990. A new selective, differential agar medium for isolation of Vibrio cholerae O1:PMT (polymyxin-mannose-tellurite) agar. Jpn J Med Sci Biol 43: 37-41.

Shohat M, Mimouni D, Ben-Amitai D, Sredni B, SRedni D, Shohat B AND DAVID M. 2005. In vitro cytokine profile in childhood alopecia areata and the immunomodulatory effects of AS-101. Clin Exp Dermatol 30: $432-434$.

Soni D, GuPTA PK, KUMAR Y AND CHANDRASHEKHAR TG. 2005. Antibacterial activity of some unsymmetrical diorganyltellurium(IV) dichlorides. Indian J Biochem Biophys 42: 398-340.

SREDNI B ET AL. 2004. Hair growth induction by the Tellurium immunomodulator AS101: association with delayed terminal differentiation of follicular keratinocytes and ras-dependent up-regulation of KGF expression. FASEB J 18: 400-402.

SREDNI B ET AL. 2007. Multifunctional tellurium molecule protects and restores dopaminergic neurons in Parkinson's disease models. FASEB J 21: 1870-1883.

SOK DE AND KIM MR. 1992. Selective inhibition of Zn2+glycerophosphocholine cholinephosphodiesterase by tellurium tetrachloride. Biochem J 284: 641-643.

Summers AO AND JACOBY GA. 1977. Plasmid mediated resistance to tellurium compounds. J Bacteriol 129: 276281 .

Sun X, Wong JR, Song K And Chen LB. 1996. Anticarcinoma activity of a novel drug, 3-ethyl-3'-methyl-thiatelluracarbocyanine iodide (Te), a tellurium-containing cyanine targeted at mitochondria. Clin Cancer Res 2: 1335-1340.

TAYLOR A. 1996. Biochemistry of Tellurium. Biol Trace Elem Res 55: 231-239. 
TAylor DE, Rooker M, KeElan M, NG LK, Martin I, Perna NT, Burland NT and Blattner FR. 2002. Genomic variability of $\mathrm{O}$ islands encoding tellurite resistance in enterohemorrhagic Escherichia coli $\mathrm{O} 157: \mathrm{H} 7$ isolates. J Bacteriol 184: 4690-4698.

Tremaroli V, Fedi S And Zannoni D. 2007. Evidence for a tellurite dependent generation of reactive oxygen species and absence of a tellurite mediated adaptive response to oxidative stress in cells of Pseudomonas pseudoalcaligenes KF707. Arch Microbiol 187: 127-135.

TURnER RJ, WEINER JH AND TAYLOR DE. 1994. Utility of plasmid borne tellurite resistance determinants for the bio-recovery of tellurium. Biorecovery 2: 221-225.

URIG S AND BECKER K. 2006. On the potential of thioredoxin reductase inhibitors for cancer therapy. Seminars Cancer Biol 16: 452-465.

Wagner M, Toews AD And Morell P. 1995. Tellurite specifically affects squalene epoxidase - investigations examining the mechanism of tellurium-induced neuropathy. J Neurochem 64: 2169-2176.

Wagner-Recio M, Toews AD AND Morell P. 1991. Tellurium blocks cholesterol synthesis by inhibiting squalene metabolism: preferential vulnerability to this metabolic block leads to peripheral nervous system demyelination. J Neurochem 57: 1891-1901.

Whitham GH. 1995. Organosulfur Chemistry. Oxford University Press: Oxford.

Wieslander E, Engman L, Svensjö E, Erlansson M, Johansson U, Linden M, ANDERSSON CM AND BRATTSAND R. 1998. Antioxidative properties of organotellurium compounds in cell systems. Biochem Pharmacol 55: 573-584.
Yamada A, Miyagishima N And Matsunaga T. 1997. Tellurite removal by marine photosynthetic bacteria. $\mathrm{J}$ Mar Biotechnol 5: 46-49.

Yilmaz A, Gun H And Yilmaz H. 2002. Frequency of Escherichia coli O157:H7 in Turkish cattle. J Food Protect 65: $1637-1640$.

Yosef S, Brodsky M, Sredni B, Albeck A And AlBECK M. 2007. Octa-O-bis-(R,R)-Tartarate Ditellurane (SAS) - a novel bioactive organotellurium(IV) compound: synthesis, characterization, and protease inhibitory activity. ChemMedChem 2: 1601-1606.

Yu L, He K, Chai D, Yang C And Zheng O. 1993. Evidence for telluroaminoacid in biological materials and some rules for assimilation of inorganic tellurium by yeast. Anal Biochem 209: 318-322.

ZADIC PM, CHAPMAN PA AND SIDDONS CA. 1993. Use of tellurite for the selection of verocytotoxigenic Escherichia coli O157. J Med Microbiol 39: 155-158.

Zadic PM, Davies S, WhitTAKer S AND Mason C. 2001. Evaluation of a new selective medium for methicillin-resistant Staphylococcus aureus. J Med Microbiol 50: 476-479.

Zanaroli G, FEdi S, CARneVAli M, FAVA F AND ZANNONI D. 2002. Use of potassium tellurite for testing the survival and viability of Pseudomonas pseudoalcaligenes KF707 in soil microcosms contaminated with polychlorinated biphenyls. Res Microbiol 153: 353-360.

ZANNONI D, BORSETTI F, HARRISON JJ AND TURNER RJ. 2008. The bacterial response to the metalloids Se and Te. Adv Microbiol Physiol 53: 1-36. 